УДК 78.085.7:398.3(497)(049.3)

https://doi.org/10.55302/MF2077-78131k

Стојанче Костов

\title{
ОБРЕДНИОТ КАРАКТЕР НА ОРОВОДНИТЕ ПЕСНИ (избрани примери од Источното игроорно подрачје на Македонија)
}

Апстракт: Во текстот ќе стане збор за обредниот карактер на ороводните песни, односно ќе се направи обид да се анализираат неколку примери од Источното игроорно подрачје на Македонија. Предмет на анализа ќе бидат ороводни песни, кои се изведуваат на повеќе празници од пролетниот циклус, како што се: Лазарева Сабота, Ѓррѓовден и Велигден, како и песните што се изведуваат за време на свадбениот циклус. Целта на трудот е да се направи анализа во однос на нивните обредни карактеристики што се практикувале во минатото.

Клучни зборови: ороводни песни, пролетен циклус, свадбен циклус, обреден карактер.

Ороводните песни претставуваат значаен дел од обредните активности за време на празнувањата, а исто така заземаат важно место и во свадбениот циклус. Најнапред е значајно да го објасниме потеклото на ороводните песни како синкретична форма. Според Пенушлиски, потеклото на усното народно творештво, на фолклорот, води кон најстарите епохи на историјата на човештвото, односно кон првите стапалки на човечката култура и појавата на говорот кај луѓето. Тогаш се појавила и првата уметност на човекот составена од елементи на игра, мелодија и говор, која била неразделно поврзана со трудовите процеси (Пенушлиски, 1999, 12). Во оваа единствена уметност централно место имала играта. Ритамот и зборот станале основа на усното и музичкото творештво, како што посочува Пенушлиски, додека пак поврзаноста на играта, мелодијата и зборот - важна карактеристика на фолклорното творештво. Тоа е првобитен синкретизам или првобитна уметност. Првобитниот синкретизам најдобро се отсликува во ороводните песни. Тие се претставени како посебен вид творби проследени со разни магиски практики во кои, во основата, стои образецот на организирано движење. Како што истакнува Величковска, македонските ороводни песни, во животот на традиционалната селска зедница, се тесно поврзани со особеностите на локалните системи на народната ороводно-пејачка култура (Величковска, 2012, 28).

Во однос на обредите и обредните игри, каде што се сретнува играње и пеење, е значајно да го споменеме тврдењето на Јанковиќ, каде што се вели дека религиозните или култните игри се остатоци од паганските времиња (Јанковић, 1939, 19). Овој податок го потврдува и Пенушлиски, кој истакнува дека „бесовските игри и песни“ што ги осудувала и прогонувала званичната црква, всушност биле пагански култни обреди во чест на боговите и на духовите, кои се изведувале уште од првобитните племиња за здравје и плодност (Пенушлиски, 1999, 12). Тоа што за обредните игри може да се каже е дека се поврзани за одредено време, односно за празник или за одредено 
време во годината, а суштински треба да бидат молитва за благодет што недостасува или за прославување на природата што се буди.

За да се разбере обредниот карактер на ороводните песни, треба да се објасни поимот обред. Според Петреска, под поимот обред се подразбира утврден начин на симболичко однесување пренесуван со традицијата, чија цел е да се пренесе општествената порака и на тој начин обредот претставува значаен дел на вербалното ниво на комуникација. Петреска уште посочува дека секоја обредна активност се состои од низа симболи - најситни единици на обредот, кои можат да бидат предмети, активности, настани, односно секоја од нив има своја визуелна, вербална, просторна и временска димензија и кои се изразуваат истовремено и се кондензираат во единствен настан (Петреска, 2002, 42).

Кога станува збор за ороводните песни, вербалната димензија е претставена преку играњето и пеењето. Во однос на играњето и на движењата, Васиќ истакнува дека основните игроорни елементи, како што се: тапкањето, вртењето и скокањето имаат значајна улога во надополнувањето на песните на оро, а танцувачките елементи во етнокореологијата можат да се протолкуваат како знаци за повикување на ветерот, растот на посевите, како и поттикнување на плодноста (Васић, 1998, 42). Просторната димензија се однесува на утврдениот простор, каде што се изведуваат ороводните песни. Во случајот на Лазарките, тоа е дворот на куќата на семејството за кое пеат и играат за благодет, или пак кога станува збор за Велигденските ороводни песни, тоа е на сретсело. Временската димензија се однесува на времето кога се слави одреден празник. Па, така, Лазарките се изведуваат на Лазарева сабота, Велигденските ороводни песни, строго на празникот Велигден, Ѓ урѓовденските на Ѓ урѓовден итн. Досега наведените елементи ги содржат и ороводните песни од свадбениот циклус. Вербалната димензија останува иста, односно ја содржи синкретичноста на играње и пеење, но во овој случај содржината на текстуалниот дел на песните е со поинаква намена или поточно, песните се пеат за невестата, за зетот, за кумот. Просторната димензија е поврзана со изведувањето на ороводните песни во дворот на куќата на младоженецот и на невестата. Временската, пак, е за време на одржување на свадбата и таа најчесто трае по неколку дена. Сите споменати елементи, изразувајќи се истовремено, создаваат еден единствен настан, кој всушност го одредува обредниот карактер на ороводните песни.

Објаснувајќи ги скриените и отворените функции на самиот обред, Петреска истакнува дека манифестната функција на обредот би било проучувањето на неговите магиско-религиозно активности, кои, учесниците ги изведуваат свесно и се уверени дека тие имаат практично, вистинско дејство, додека латентната функција би била скриената порака, односно социолошката и психолошката димензија што, за специјалистите, е крајна цел за објаснувањето на функцијата на обредот, додека за изведувачите таа е главно несвесна (Петреска, 2002, 43). На ова може да се надоврзе и тврдењето на Тарнер, кое зборува за три значајни симболички параметри: 1. јавна смисла, која се однесува на експлицитните цели на обредот и целосно осознаени исполнители; 2. латентна смисла, која се наоѓa на граница на 
субјективното сознание, но е способна да биде целосно осознаена; 3. скриена смисла, целосно неосознаена, која се однесува на базичното инфантилно искуство, општо за сите човечки суштества (Тарнер, 1983, 41).

Во минатото ороводните песни, како што посочува Величковска, претставувале своевидна форма на општествен живот на селските заедници. За нив особено карактеристично е кружното играње како форма на исполнување, со оглед на тоа што во ороводниот круг се случуваат естетски соединувања кај сите литературни - музички - драмски компоненти, круг што се здобива со посебно функционално и структурно-организациско значење (Величковска, 2016, 44). Според Рогачевскаја, учесниците во ороводниот круг, преку песната, се здобиваат со општи карактеристики што дејствуваат, ги набљудуваат настаните во просторот, на кругот, вршејќи разни дејствија (Рогачевская, 1980, 9).

Како главен исполнител и носител на целокупната обредно-пејачка ороводна традиција е жената. Таа игра најзначајна улога кога станува збор за ороводните песни со обреден карактер, како во календарскиот циклус, така и во некалендарскиот циклус. Во однос на календарскиот циклус или поконкретно за празникот Св. Лазар или Лазарева сабота, ороводните песни што ги пеат во некои предели на Македонија претставуваат и иницијациски обред на премин, а обредните поворки Лазарки, се типичен пример за оваа појава. Познато е дека лазарки ${ }^{2}$ можат да бидат само немажените и несвршените девојки до осумнаесетгодишна возраст, а етнокореологот Димоски забележува дека девојките што треба да се свршат таа година, изигруваат последен пат лазарско оро (се мисли на ороводна песна), што претставува иницијација односно преминување од моминскиот во брачниот живот (Димоски, 1973, 57). Овој начин на иницијација во минатото бил распространет во повеќе етнички предели на Македонија, при што строго се практикувал обредот на премин, кој всушност претставува обред на сепарација. За обредите на сепарација Петреска објаснува дека тие вклучуваат симболичко однесување, означувајќи одделување на личноста или групата од занимањето во поранешното место во социјалната структура или одделување од определена културна положба (Петреска, 2002, 44).

Величковска најсликовито ја објаснува формацијата на лазарките и начинот на пеење и играње преку типот на песни на вртење или на играње $e^{3}$, кој е застапен во повисоките планински села на Кривопаланечкиот Регион, каде што вели дека: „Девојките фатени во обредното оро изведуваат песни антифоно, најнапред започнуваат да пеат првите две девојки, а потоа настапуваат другите две, па третите, во зависност од бројот на девојките во

\footnotetext{
${ }^{1}$ Улогата и функцијата на Лазарките се потврдува преку нивната обредност, пеење и играње, која е задолжителна за девојчињата во поширокиот македонски ареал, задржувајќи ја притоа својата архаичност со антифон начин на пеење во формација на две или три групи по три девојки (Величковска, 2012, 31).

2 Според Величковска, постојат три типа на лазарски песни од Кривопаланечкиот Регион: 1) на одење или на шетање, 2) на стојање и 3) на вртење или на играње (Величковска, 2012, 30).
} 
обредното оро“ (Величковска, 2012, 30). За овој тип песни, според авторката, е карактеристично играњето со преплетување на нозете и антифониот начин на пеење, а таков пример е песната Јовде се игра големо оро (Величковска, 2012, 184). Преку едноставниот начин на играње со преплетување како и пеење на мелодиска линија, која на извесен начин ја разбива едноличноста на музичкиот дел во песната, се отсликува обредноста кај споменатата лазарска песна. Начинот на играње со преплетување претставува еден од најархаичните типови на игроорни образци во ороводните песни, а ваквиот тип на играње го изразува обредниот карактер на ороводната песна.

Во повеќе региони на Источното игроорно подрачје ороводните песни наоѓаат посебен одраз во традиционалното народно пеење. Еден од нив е Кратовскиот Регион, каде што најчесто ороводните песни се изведуваат во форма на кружни движења на оро. Тие се дел од празнувањата поврзани за календарскиот циклус обичаи, како што посочува Величковска, а се пеат со играње на играориште на соборот (пред црква или на сретсело), за време на празнувањата во селските заедници (Величковска, 2016, 44). Како пример може да ги посочиме песните од кај Величковска: Тодоро, Тодоро Влаино и Здравче Венче, иявќе мирииливо (Величковска, 2016, 159-162).

Ороводната песна Китче ми падна бре Величе, која исто така потекнува од Кратовскиот Регион, може да се претстави како интересен феномен на песна, која спаѓа и во календарскиот, но и во некалендарскиот циклус. Според сознанијата на Величковска, песната се пее на собор на големиот празник Велигден, а исто така и за време на свадбениот циклус, поточно на блага ракија (Величковска, 2016, 44).

Ороводните песни се карактеристични и за свадбарското ороводно пеење, а се изведуваат најчесто во понеделникот кога жените одат на блага ракија. Тоа се песни со хумористична содржина и се пеат на сметка на младата невеста како во примерот Мори Видо, неверна другачко. Оваа песна девојките ја пеат како подбив на некоја нивна штотуку мажена другарка, која многу избирала. Во примерите што ги сретнуваме кај Величковска, освен за невестата, исто така се пееле песни и за другите главни ликови во свадбениот церемонијал, кои најчесто имале хумористична содржина. Таков пример е песната Нели не си кадар девере, во моментот кога сплетените венци една девојка ги подава на деверот, кој треба да ги откупи (Величковска, 2016, 46).

Според Величковска, на ороводните песни својствена им е строгата ритмичка синкретична уметност, во која се соединети пејачки, кореографски и драмски елементи. Тематиката на ороводните песни опфаќа многу аспекти од народниот бит, додавајќи им популарност, виталност, а сето тоа го определи естетското значење на ороводното пејачко творештво, кое претставува сѐ уште живо музичко-фолклорно изразување и сведоштво за постоење на една широко развиена игроорно-пејачка традиција во Кратовскиот Регион. Обредната пејачка традиција, како што истакнува Величковска, во овој регион имала своја функција, свое место, време и свој начин на изведба во традиционалните заедници. Некои продолжиле и денес да опстојуваат, а се манифестираат за време на празнувањата и на разните свечености, поврзани за годишните празнувања и со свадбата. 
Ороводните песни се изведувале за време на локалните празнувања на селските заедници, а се изведуваат на соборите преку целата година и во областа на Осоговијата, Малешевско-пијанечкиот и Овчеполскиот музичкофолклорен ареал. Овие три ареали како и Кратовскиот, може да се каже дека претставуваат простор, каде што најмногу била застапена ороводната пејачка традиција кога станува збор за североисточните и источните предели на Македонија. Така, на пример, за време на Ѓурѓовденските празнувања на соборот во с. Истибања, Виничко, се пее многу познатата ѓурѓовденска ороводна песна Мори Ѓуре, жално Ѓуре (Величковска, 2012, 176). Типичен пример на ороводна песна, која има обреден карактер и се пее исклучиво на празникот Ѓруѓовден во Овчеполскиот Регион е песната Овц̧и пасе Маргита девојка, која потекнува од селото Амзабегово. Според Величковска, како едно од најзначајните празнувања во посочениот регион е празникот Тодорица (Величковска, 2012, 32). За време на Тодоричките празнувања жените, покрај обавувањето на разни обредни дејствија, ја играат и ја пеат познатата ороводна песна, Тодоринко баш именко (Величковска, 2012, 173). За време пак на Петковденските празнувања во овој ареал, како што се забележува во записите на Величковска, е карактеристично пеењето и играњето на многу популарната ороводна песна Свети Петко сиромашен, во која се пее за забраната за вршење полска работа за време на овие празнувања (Величковска, 2012, 174).

Во записите на Пајтонџиев се сретнуваат песни, кои се изведувале за време на свадбениот циклус од неколку етнички предели од Источното игроорно подрачје на Македонија како што се песните: Оj, Стано, Стано; Брала Неда, море, зелен здравеи; Ранила мома рано на вода; Невесто, невесто итн. Но, најголемо внимание ќе обрнеме на песната Невесто, невесто поради тоа што има(ла) исклучително обреден карактер. Кога се делела плетеницата во Берово, невестата и сватовите оделе на реката на вода и фрлале пари во водата, а откако ќе се врателе дома, каде што се делела плетеницата, играле ора со песни (Пајтонџиев, 1973, 60). Овде главна улога имала свекрвата, која била накитена на главата и ја започнувала ороводната песна:

\author{
Невесто, невесто, \\ сношчи, море, доведена, \\ отсутра станала \\ и се провикнала, \\ на свекор викнала...
}

(Пајтонџиев, 1973, 289).

Сличен пример на свадбарска ороводна песна сретнуваме и во записите на Величковска со наслов Невесто, невесто, сношчи си доведена, која потекнува од с. Стамер, Пијанец (Величковска, 2012, 180). Овде се работи за варијанта на текстот, кој има слична содржина како претходната, со малку поразлична мелодиска линија, но го имала истиот обреден карактер. Значајно е да се напомене дека овие песни, кои во минатото се пееле во строго 
определен момент од свадбата и имале посебно значење за целокупниот свадбен циклус, со текот на времето, се случувало да се играат и да се пеат на соборите и на празниците во текот на целата година, со што ја губеле обредноста. Таков податок може да се забележи кај Пајтонџиев, каде што за ороводната песна Ранила мома рано на вода, се вели дека е свадбарска, но се играла на секакви веселби (Пајтонџиев, 1973, 150).

Во Кумановската Област, според Јанковиќ, во триесеттите години на минатиот век биле зачувани и голем број ороводни песни, како што се: Појдох по пута по камената; Нана карала девојче; Седело Јане под бела лозица; Дилбер Јанка по двори се шече; Дал грми, дал се гора тресе; Ситан камен до камена; Коло води Васа; Жали Заре да жалимо; Паде магла више Рајиновиа; Ките ќерко кој лупа на пенцер; Ситан бибер; Китице; Данице не ми лажи брата; Оj, ти, Маро Дилиндаро (Јанковић, 1939, 152). Во нивните записи не може да се најде прецизен податок за карактерот на сите наведени песни, односно дали некои од нив се обредни и кога се изведувале, туку само се наведени дека се играле со песна. Од таа причина не може да се анализира нивниот карактер, но сепак вреди да се споменат како ороводни песни, кои некогаш се изведувале во овој ареал.

Според досега изнесеното, за ороводните песни може да се констатира дека претставувале неизбежен дел од празнувањата за време на календарскиот циклус, локалните празнувања на заедницата, но и за време на свадбениот циклус. Тие се широко застапени во повеќето етнички предели на Источното игроорно подрачје на Македонија. Обредниот карактер се определува преку нивната вербална димензија, која се однесува на играњето и пеењето како синкретична форма, просторната димензија, која го претставува утврдениот простор, каде што се изведуваат ороводните песни и нивната временска димензија, која се однесува на празникот на кој се изведуваат. Строго утврдените норми на изведување најчесто можат да се забележат кај Лазарските ороводни песни, како што е на пример ороводната песна Јовде се игра големо оро, кој претставува најтипичен пример на обредено пеење и играње за време на празникот Лазарева сабота во североисточните предели на Македонија.

Постојат и примери на ороводни песни, кои се изведувале и за време на одреден празник, но и за време на свадбениот циклус, како што е песната Китче ми падна бре Величе. Исто така, постојат и ороводни песни, кои се изведувале за време на свадбениот циклус во строго определен момент на изведување, како што е песната Невесто, невесто, која имала обреден карактер, но исто така се случувало истата песна да биде изведувана и на најразлични собори и веселби, каде што веќе ја губи својата обредност.

Песните Овци пасе Маргита девојка, која се изведувала на празникот Ѓурѓовден, Тодоринко баш именко, изведувана за време на Тодорица, како и песната Свети Петко сиромашен, која преставувала неизоставен дел од Петковденските празнувања, кога се изведувале на посочените празници имале обреден карактер. Но, со текот на времето почнале да се изведуваат и на соборите и веселбите, со што ја загубиле својата обредност. 
Ова беше само една кратка анализа на обредниот карактер на некои примери на ороводни песни од Источното игроорно подрачје на Македонија, кои се сметаат за најтипични, но, секако дека можат да се посочат уште голем број други примери на ороводни песни од овој богат музичко-фолклорен ареал.

\section{ЛИТЕРАТУРА}

ВАСИЋ, О. (1998). Улога полова у обредној пракси нашег народа, Постструктуралалистичка наука о музици, Специјално издање „Нови звук“, СОКОЈ-МИЦ при ФМУ, Београд.

ВЕЛИЧКОВСКА, Р. (2012). Македонското традииионалнао народно пеење со хрестоматија и мелопоетска анализа. Скопје: Маска.

ВЕЛИЧКОВСКА, Р. (2016). Обредната пејачка традиција во Кратовскиот регион, Општинска установа. Кратово: Музеј на град Кратово.

ДИМОСКИ, М. (1973). Лазарските ороводни песни во Струга и Струшко и нивните етнокореолошки карактеристики. Македонски фолклор, год. VI, бр. 12, Институт за фолклор, Скопје, стр. 57-62.

ЈАНКОВИЋ, Љ. и Д. (1939). Народне игре, књига III. Београд.

ПАЈТОНЏИЕВ, Г. (1973). Македонски народни ора. Скопје: Институт за фолклор.

ПЕНУШЛИСКИ, К. (1999). Македонски фолклор, Историски преглед. Скопје: Матица македонска.

ПЕТРЕСКА, В. (2002). Свадбата како обред на премин кај Македонците од брсјачката етнографска ичелина. Скопје.

РОГАЧЕВСКАЯ, Е. М. (1980). О руском хороводним творечестве. Актуальные проблемы современной фолкъристики. Сборник статей и материалов. Ленинград: Издателство, Музыка, Ленинградское отделение.

TAPHЕР, В. (1983). Символ и ритуал. Москва: Издательство „Наука“.

Stojanche Kostov

\section{THE RITUAL CHARACTER OF THE FOLK SONGS COMPAINED WITH DANCE (THROUGH SELECTED EXAMPLES OF MACEDONIAN EASTERN DANCE AREA)}

Summary

The text treats the ritual character of folk songs that are compained by dance. It was made an attempt to analyze several examples from the Eastern dancing area of Macedonia. The subject of analysis was the folk songs that are accompained by dances performed on several spring cycle holidays such as Lazara, St. George and Easter, as well as songs performed during the wedding cycle.

The purpose of this paper was to make an analysis of their ritual characteristics practiced in the past. 